\title{
Bible Journaling as a Spiritual Aid in Addiction Recovery
}

\author{
Amanda Dillon
}

Citation: Dillon, Amanda. 2021. Bible Journaling as a Spiritual Aid in Addiction Recovery. Religions 12: 965 https://doi.org/10.3390/rel12110965

\section{Academic Editors:}

Bernadette Flanagan, Noelia Molina and Greg Peters

Received: 9 August 2021

Accepted: 22 October 2021

Published: 3 November 2021

Publisher's Note: MDPI stays neutral with regard to jurisdictional claims in published maps and institutional affiliations.

Copyright: (C) 2021 by the author. Licensee MDPI, Basel, Switzerland. This article is an open access article distributed under the terms and conditions of the Creative Commons Attribution (CC BY) license (https:/ / creativecommons.org/licenses/by/ $4.0 /)$.
School of Humanities, Waterford Institute of Technology, X91 K0EK Waterford City, Co. Waterford, Ireland; adillon@wit.ie

\begin{abstract}
Bible Journaling is a trend of the past decade whereby readers make creative, visual interventions in their Bibles, using coloured pens and pencils, watercolours, stickers and stencils, highlighting texts of particular resonance. Journaling, in its more conventional written forms, has long been recognised as a pathway to spiritual development. Significantly, Bible journaling is almost exclusively practiced by women and has a high level of interpersonal interaction attached to it, through open and mutual sharing of these creations, through various online social media fora. Gleaned from the sharing of women who journal for spiritual support, this article examines the role Bible journaling plays in aiding recovery from drug addiction. Multimodal analysis is a methodological approach that provides a structured semiotic framework in which to closely examine every feature of a creation such as a journaled page of a Bible, to examine how the journaler has made meaning of a text through their interventions on the page. Appreciating every mark, choice and placement of image, colour, typography as a motivated sign revealing the interest of the creator, the sign-maker, a detailed multimodal analysis is conducted of one page of a recovered drug-user's journaled Bible. As shall be demonstrated, profound insights into the appropriation of sacred texts for the spiritual life of a recovering addict can be gleaned in this process. Bible journaling reveals itself to be a highly valuable spiritual practice for those in addiction recovery. This interdisciplinary paper uniquely brings a methodological approach from the field of semiotics to the field of spirituality. Both the methodological approach and the subject of sacred text journaling may be of particular interest to spiritual directors, across many religions with a foundational sacred text, as a means whereby adherents can engage with a text in a deep, contemplative and creative practice that is personally, spiritually sustaining and motivating during a difficult phase of life.
\end{abstract}

Keywords: Bible journaling; biblical spirituality; drug addiction; journaling addiction; addiction recovery; multimodality; multimodal analysis

\section{Introduction}

Within spirituality research, the practice of journaling has long been recognised as a particularly valuable and powerful means of self-reflection, discernment, discovery and healing (Progoff 1975, 1983; Budd 2002; Adams 2004; Pennebaker 2004; Moon 2004; Milner 1986; Lukinsky 1990). In recent times, a new phenomenon has emerged that adds an interesting dimension to the many, varied practices of journaling already carried out. Of course, it is recognised that many journalers have made recourse to the biblical text in the past (Peace 1995; Cepero 2008; Leonard 1995), but Bible journaling as researched in this article is a strikingly new development for two key reasons. Firstly, specially designed journaling Bibles are now printed with a wide, blank margin, alongside the text, on the page-leaving space for the reader's own reflections in this wide margin. It is a bespoke product where for the first time the journaler journals directly in their Bible. Secondly, this publishing innovation has sparked a new trend of journalers not only writing in these margins, as first envisaged by the publishers, but, significantly, also making other creative interventions in their Bibles. Included here are twelve photographs (Figures 1-12) of journaled pages created by the participants in this study. These pages shall not be commented on individually, apart from Figures 7 and 8. They are included to demonstrate 
to the reader the great richness and diversity of personal engagement that is evident on these pages: the chosen texts for reflection as well as a variety of meaning-making interventions made on the page, from naïve drawing with pencil crayons to the complex collation and overlaying of cut and paste images, symbols, stickers, tickets, textures, lettering, cards and other ephemera.

As can be seen in these images, there is a shift away from a predominantly written, verbal form towards a multimodal form, including the visual-drawing, painting, sketching and tracing - and pasting of images and patterns, in this journaling practice. More generally, a move towards creative and visual journaling practices is evidently popular (Hieb 2005) and specifically in relation to addiction recovery (Maisel and Raeburn 2008). Furthermore, the sense of touch is engaged with the inclusion of textures in the way of stickers, ribbons, felt, cords, tassels and bobbly, embossed papers. The results are highly innovative and creative, multimodal interventions being made in printed Bibles, reflective of the reader's own personal engagement with their sacred scriptures (Dillon 2020). 


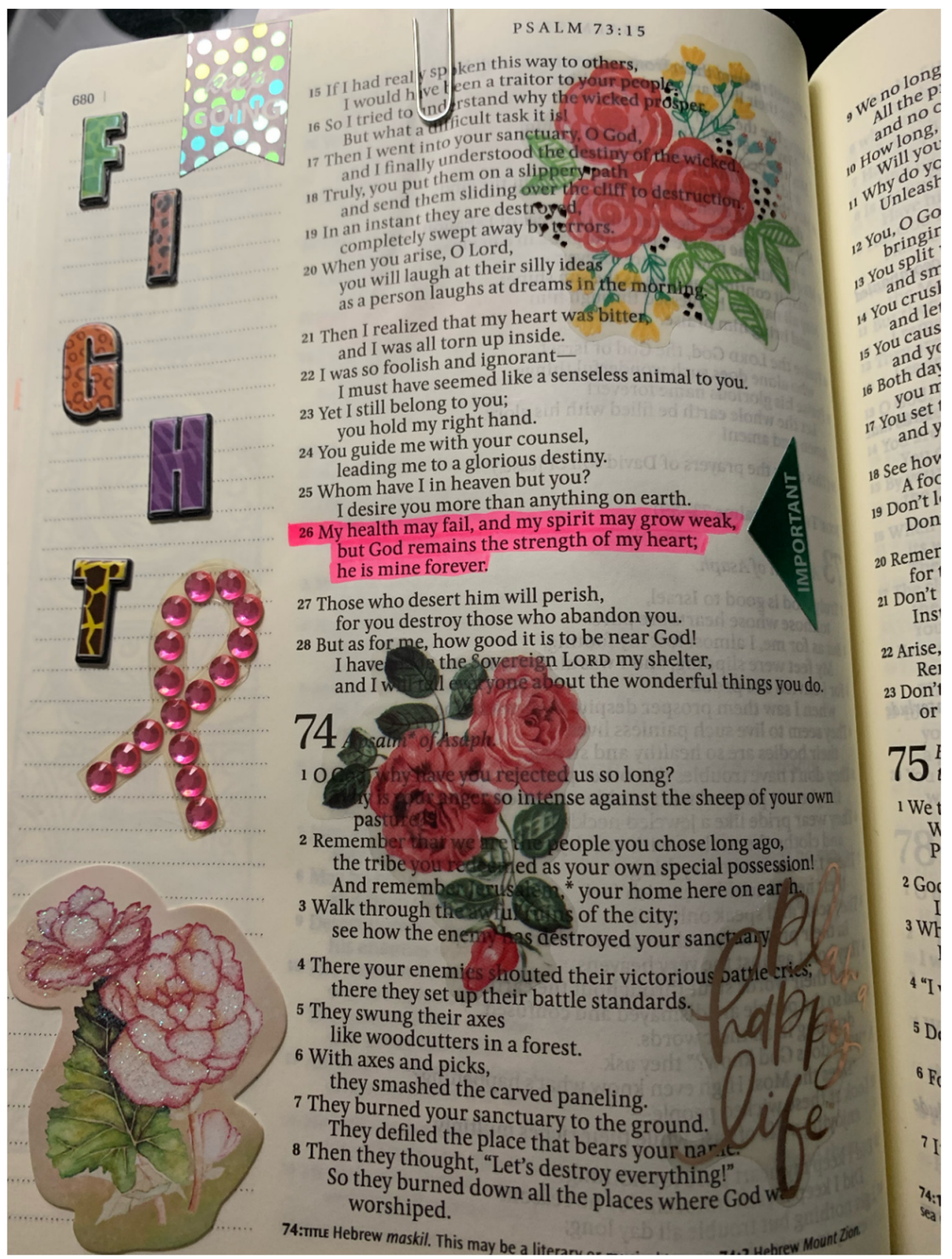

Figure 1. Psalm 73:26. With kind permission of the journaler.

Bible journaling of this type has emerged as a hugely popular spiritual practice among Christian women, in particular, as a means of engaging in a profound way with the biblical text. For many believers, the Bible is the primary resource for their personal faith in the Christian God. ${ }^{1}$ Many churches in North America now have Bible journaling groups that gather weekly to do this together, often combined with Bible study and more experienced practitioners offering demonstrations of creative ideas (Fischer and Peiffer 2019; Nichols Hickman 2013). Beyond this, social media also provides a widely used platform for sharing ideas, skills, reviews of different journaling Bibles and materials and, most importantly, the journalers' own pages and artworks. Many Bible journaling groups have large numbers of followers on Facebook especially, one in the region of forty thousand members, and there is lively interest and activity on Instagram and Pinterest.

As shall be shown in this article, Bible journaling has proved highly beneficial for many women in recovery from various addictions. Addiction is at once a social issue 
and a spiritual issue (Alexander 2008; Plante 2018; Bedi and Pereira 2020). There is much written and produced about the opioid addiction crisis currently ravaging sectors of North American society (Stoicea et al. 2019; DeWeerdt 2019; Theroux 2017; Gibney 2021). This unprecedented rise in drug addiction sets up a formidable pastoral challenge for Christian churches, to which they have responded in different ways, some of which will be touched on here. The participants in this study have been on the receiving end of that outreach and care and concern. In the course of researching this article, I interviewed five women who kindly shared their process of Bible journaling, some of their pages and the spiritual and other benefits derived from engaging with the Bible in this way.

Firstly, I shall explain my methodological approach, followed by a brief and generalised overview of the participants in this study, before applying a multimodal analysis to one page of a journaled Bible (Figures 7 and 8). There are twelve photographs featured here of three of the women's journaled Bible pages, and as is immediately apparent, each one of these is worthy of a study all on its own. At the centre of this article is a detailed multimodal analysis of one journaled page of a Bible (Figures 7 and 8). My intention and hope is that this analysis reveals the depth of meaning that may be elicited from a close examination of the page, revealing the value of this spiritual practice for those in addiction recovery. See the end of the document for further details on references.

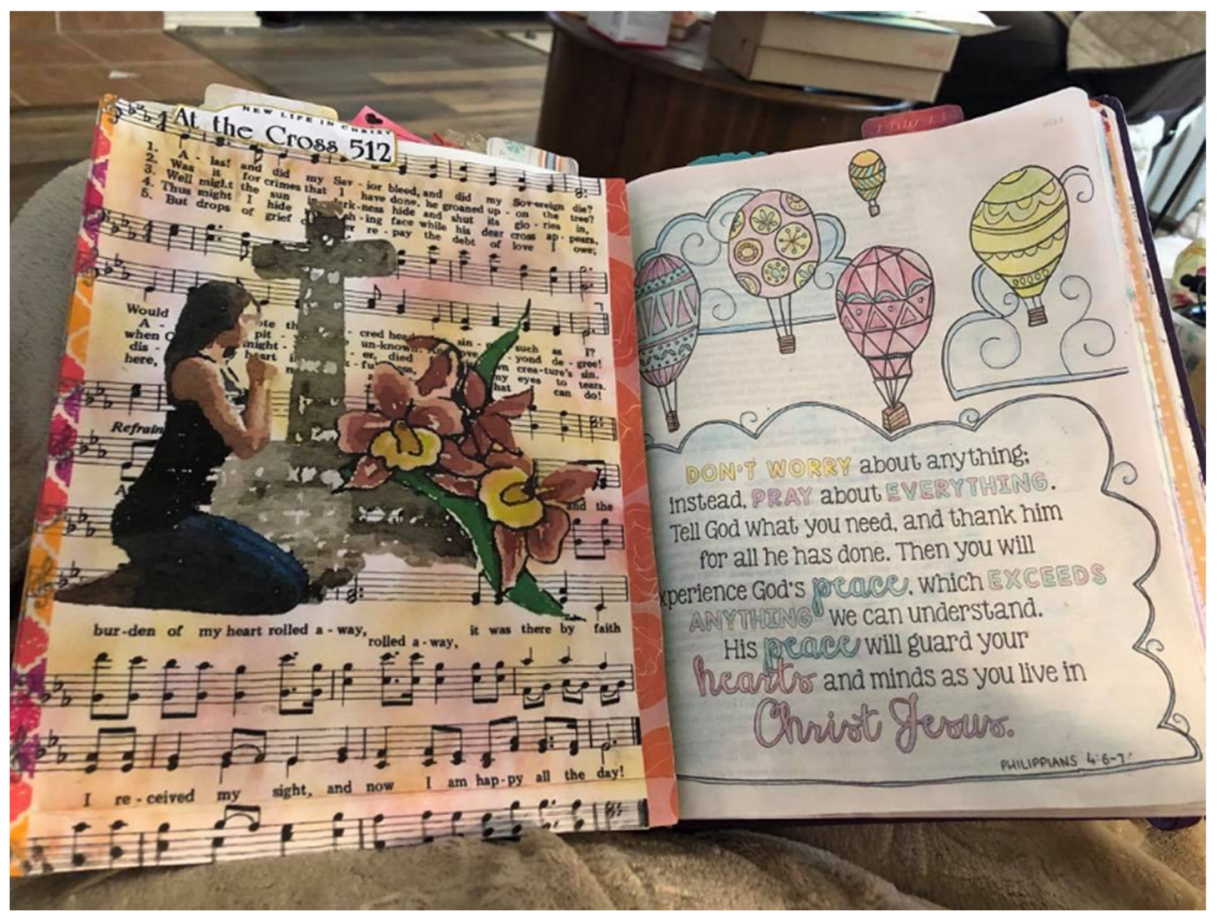

Figure 2. Philippians 4:6-7. With kind permission of the journaler.

\section{Methodology: A Multimodal Analysis}

This study initially arose out of a posting about addiction, in a very general sense, in a Facebook group, conducted with the permission of and through the administrators of the group. This is a large group with many thousands of members, dedicated to the members' common interest in and practice of Bible journaling. This quickly elicited a response from over thirty women sharing stories about many different journeys through almost every type of addiction and the role Bible journaling played in the various stages of their recovery. Many also shared images of their pages in this discussion. One of the characteristics of Bible journaling generally is the propensity of journalers to share their artworks and journaled pages by posting photos online in the multiplicity of social fora available. Special care is taken here to anonymise the women completely, bearing in mind that they may have shared one or more of these images in the public domain, beyond this 
particular Facebook group and this research process. The quotations from the women will not be linked to the featured artworks to further protect their identities and privacy.

Many women share their pages, some almost daily within the many groups like this Facebook group. I am constantly struck by the generous, supportive tone of the posts and comments, always encouraging and building up fellow journalers and readers. Any stigma that one might imagine would be associated with this topic in the context of conservative Christian Bible journaling and Bible study groups did not surface. Rather, those who identify as addicts, including addictions to food, drugs, alcohol or nicotine, receive responses of great compassion when discussing their situation, either current or historical. Five of those women then chose to engage in a semi-structured, private conversation. Three were kindly willing to share images of their journaled pages for the purposes of this publication. The reflections and testimonies of these women demonstrate that Bible journaling is a spiritual resource utilised by recovering and recovered women with addiction as a significant aid in their recovery.

There are people engaged in this practice all around the world, from South Africa to Singapore, but far and away the greatest number are located in North America. In parts this is related to:

1. Population size generally, the large population of Christians, and then the large number of Bible journaling Christians within that demographic.

2. Location of primary market for US journaling Bible publishers.

3. Energetic marketing of the Bible journaling products and peripherals (stationery, pens, highlighters, paints, paste-ins, etc.).

4. Importance of the Bible in Protestant and Evangelical churches especially.

5. Previous success of related creative, paper-based hobbies such as scrapbooking and colouring.

6. Social media platforms facilitating groups and the sharing of experience and expertise, products, etc. Of the initial over thirty women who responded to me in the social media groups, only a handful were not geographically located in North America. Those willing to participate in a research project, to discuss their experience of addiction and to share photographs of their pages were all from North America.

This article finds its theoretical foundation at the intersection of social semiotics and biblical reception history. The primary methodology employed in this article to engage with the journaled page is multimodal analysis. This is a social semiotic approach to cultural phenomena. Multimodal analysis is a theoretical semiotic framework applicable to all the semiotic modes at work simultaneously in any given artefact. In the instance of sacred text journaling these semiotic modes include densely-printed verbal text, highlighted text, handwritten words, drawings, paintings, stickers, patterned papers and tapes, colour and other additions such as ribbons. Contra Saussure-rather than finding a fixed meaning in the sign (word, image, sound, etc.) - those engaged with multimodal analysis understand meaning-making to be fluid and changeable, constantly evolving, much like language, and particular to social groups (Kress and van Leeuwen 2021; Van Leeuwen 2005; Jewitt 2014; Unsworth 2008). 
This semiotic approach understands representation as a process in which the makers of signs, Bible journalers in this case, seek to make a representation of some concept, entity or object, in which their interest in the concept or object, at the point of making the representation, is a complex one. This interest arises out of the cultural, social and psychological history of the sign-maker and is framed and focused by the specific environment in which the sign-maker produces the sign. That "interest" is the source of the selection of what is seen as the criterial aspect of the object, and this criterial aspect is then regarded as adequately representative of the object in a given context. These criterial aspects are represented in what seems to the sign-maker, at the moment of sign-making, the most apt and plausible fashion, in the most apt and plausible representational mode (drawing, painting, cutting, pasting, highlighting). Sign-makers (journalers) thus have a meaning which they wish to express and express it through the semiotic mode(s) that make(s) available the subjectively felt, in the most plausible, most apt form (Kress and van Leeuwen 2021).

Multimodal analysis provides the means to describe the social-semiotic resource (journaling) of a particular group (sacred text journalers), the group's explicit and implicit knowledge about this resource and its uses in the practices of that group. The emphasis multimodal analysis places on the criterial aspect of the word, image, colour, etc., chosen by the sign-maker, makes this the richest and most appropriate approach to analysing the multimodal work of Bible journalers. Multimodal analysis values every choice of colour, texture, highlighted word, drawn image — every intervention—as a motivated meaningmaking choice and sign on behalf of the journaler, informed by their particular social and religious context. In other words, while a drawing of a Disney mermaid character may seem incongruous or banal, when juxtaposed with and overlaid on an ancient sacred text, it must be understood as a conscious choice laden with meaning. In the context of sacred text journaling that meaning is also indicative of the hermeneutical process at play and may be revealing of personal transformation. 


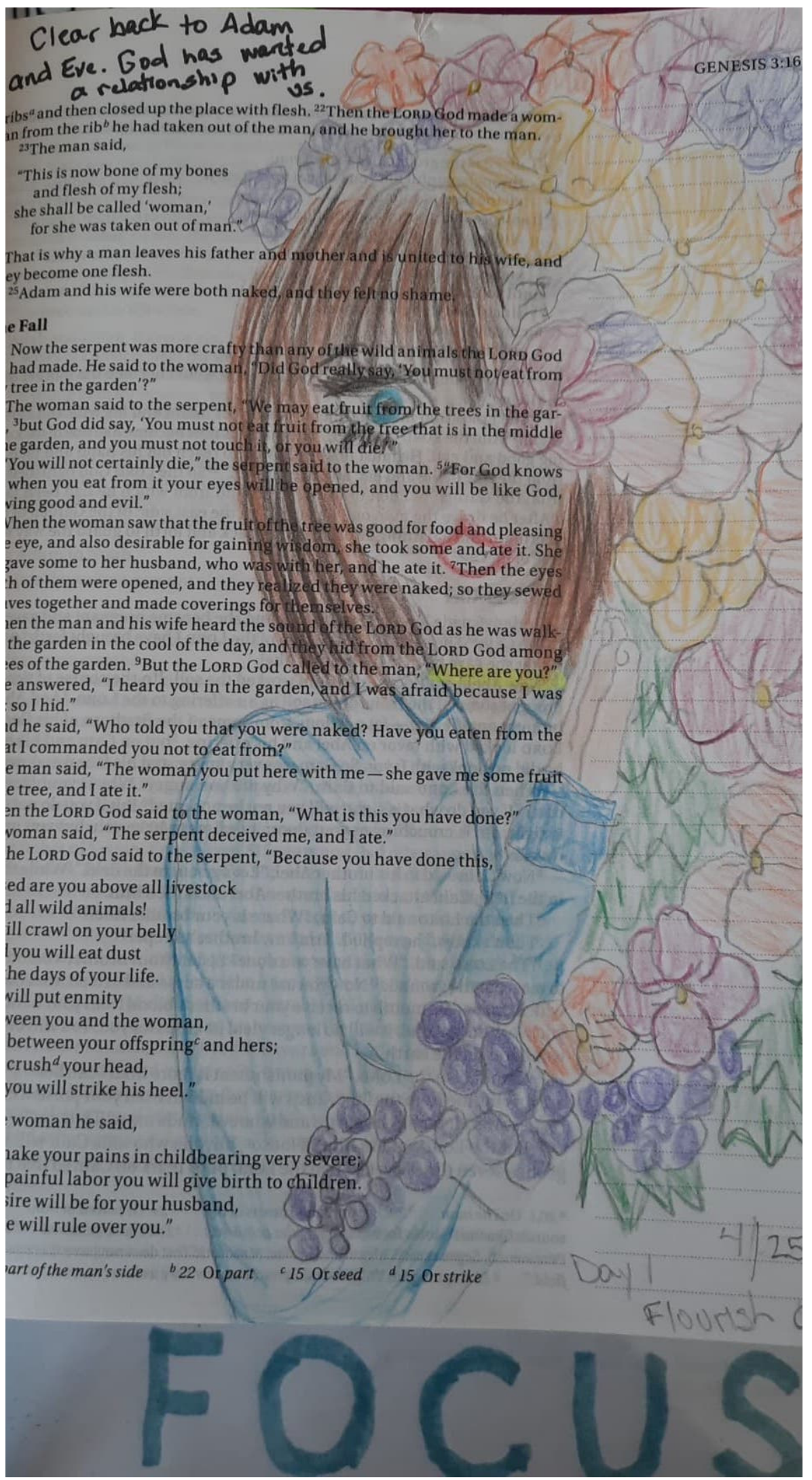

Figure 3. Genesis 3:9. With kind permission of the journaler. 


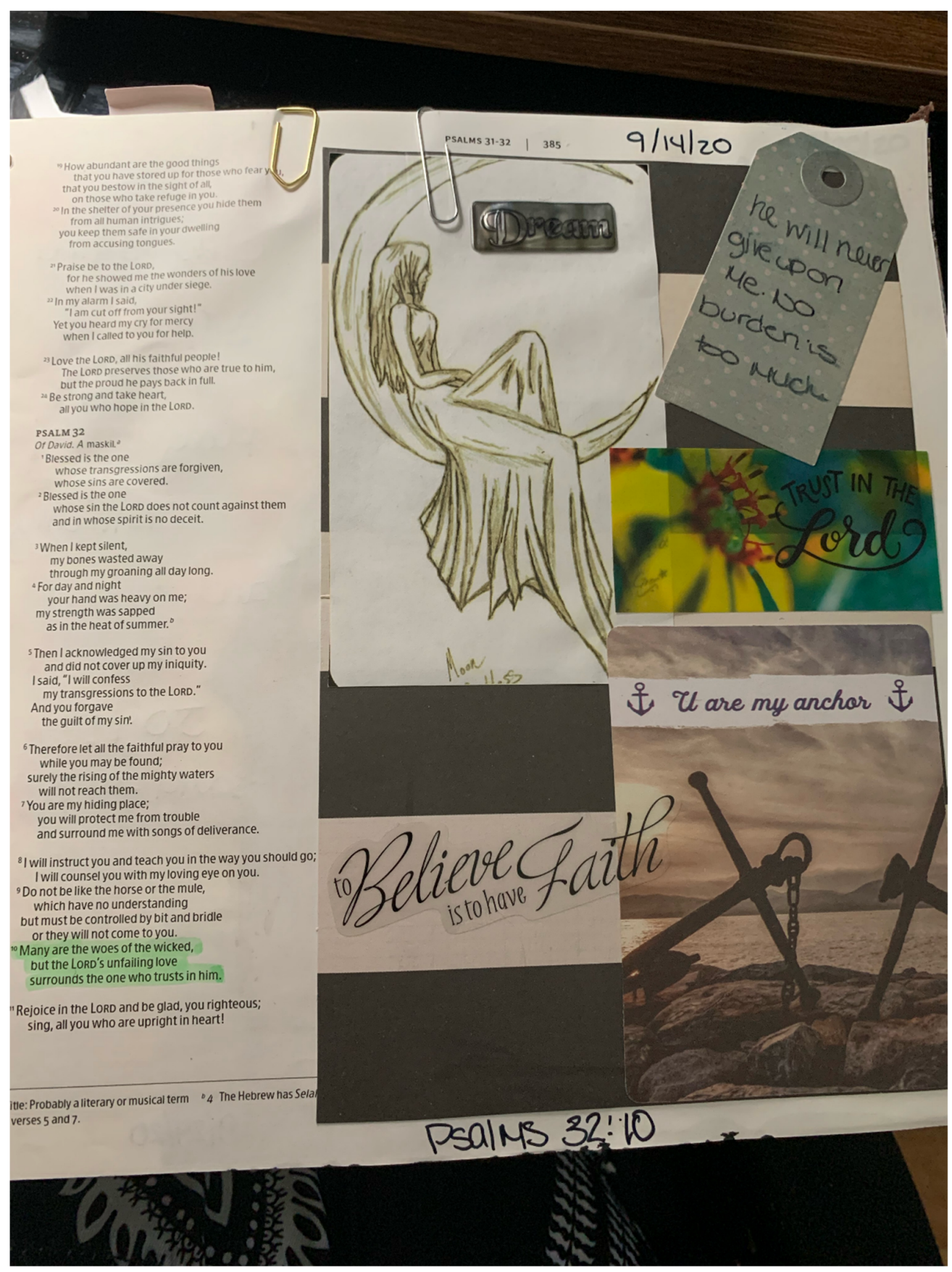

Figure 4. Psalm 32:10. With kind permission of the journaler.

\section{An Overview of the Bible Journalers and Their Practice}

The five participants were all women living in North America (Canada and the US), ranging in age from their late twenties to early fifties. The median age is mid-thirties. Four are caucasian, and one is of mixed indigenous ethnicity. They represent a broad socio-economic spectrum. In some instances, having fallen into poverty as a consequence of their drug addiction, they are still struggling to overcome that financial deprivation and establish lasting financial security in their lives. Four explicitly identify as cis-gender and heterosexual and are in marriages or long-term relationships. Three of the women have children. Two of the women had one or more of their children during the period of time that they were addicted to drugs and cite being a mother as their primary motivation for coming off drugs. 


\subsection{Pathways into Bible Journaling: Faith, Church and Addiction}

The women interviewed here have different experiences of coming to Christian faith, and in turn Bible journaling. While most had some residual knowledge and encounters with churches as children, not all did. Some of their personal accounts bear out other recently advanced autobiographical theories about how and why people can suddenly stop their using (Grisel 2019; Szalavitz 2019). Different religious organisations feature in assisting them pastorally in their recovery.

Growing up we never had Bibles or heard anything about King Jesus and my family was alcoholics and drug addicts, so of course I started using and drinking at a young age, fast forward to about maybe $7-8$ years ago, I was at my lowest, my rock bottom so to speak. I was homeless and heavy into crystal meth. I journaled a lot of that noise and it helped me to keep my head. The one moment I remember clearly was standing on a street corner asking the Lord for something, anything, as I was just done (which was also an entry in a journal). I was led to a trailer called "Love Lives Here" and there met a servant of Christ Jesus who was ministering repentance and water baptism. I never heard such things before. I then started reading the Bible and really journaling my struggle. Now, here's where the journaling really came into action-I wrote everything: my fears about never getting clean, my fears about being homeless and sleeping on the street in the murder capital of this country. I also journaled all my moments of happiness, and things I was learning in the Bible stories, and about the people around me who inspired me. Journaling became my place where I could just sort things out where I could express things and be with the Father as no one else ever read my journals. My personal sort of documented walk [with the Lord]. 


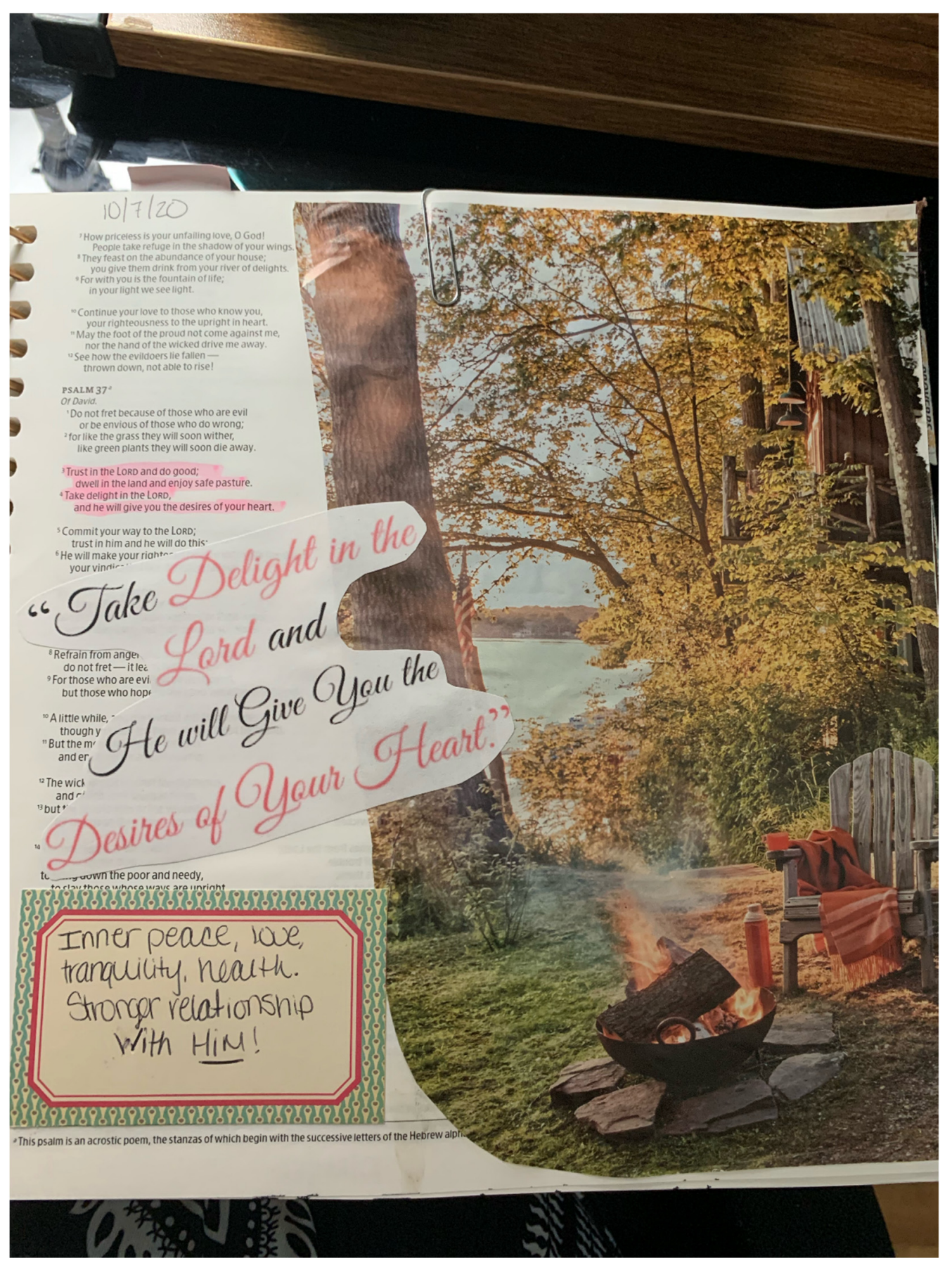

Figure 5. Psalm 37:3-4. With kind permission of the journaler.

Another women was addicted to the prescribed painkiller Percocet, ingesting 35 pills per day at the height of her addiction.

I was baptised four years ago. Before I found God I had struggled in the area of addiction. I was also selling ... I was in deep. Probably 35 Perc 30 s a day. ${ }^{2}$ I was awful. I threw all my relationships in the trash and didn't care ... I grew up with an alcoholic and distant father who pushed me away constantly. My mother, the biggest source of strength had moved out of the state. My sister and brother both struggled with some addictions too and they lived in other states too. I felt like I had no one to turn to. Then one day I just stopped cold turkey. I had had enough. I was so tired of living my life that way! My children needed me more than I needed what I was doing. It wasn't until I quit that I literally felt God calling me. 
I started out with Jehovah's Witnesses coming to my home teaching me the Bible. I was honest and told them point blank I didn't see myself attending their church but that I was more than happy to host them at my home (before Rona) in order to learn the Bible itself. She was such a sweet woman she came every week for over two years. My other half and I moved and we got a car and, finally, I was able to find my home at the Rock Church. This family here has been amazing.

Another woman describes her experience:

My addiction was to multiple substances. Pills, coke, heroine. I did a lot of things that I was not proud of. I lost my faith throughout all of that. I almost overdosed, and in that moment I snapped back to reality and said to myself I need God back in my life. I need him to help me, I need him to save me. I am now five years clean and my relationship with God is stronger than ever. Bible journaling was a new way for me to express myself and my love for God and all he has brought back into my life after losing it all to addiction.

Combinations of nicotine, alcohol and food also feature as an issue of concern. Some identify as completely addiction free now, whilst others continue to deal with nicotine and food addictions although now of lesser severity than at the height of their addiction. These ongoing conditions are a cause of anxiety for these women. "Having been a young addict I think cigarettes are more addictive than most drugs and alcohol. I wish when I had gone through treatment in 1985, they would have addressed it then, when I was 15. Back then they encouraged us to smoke cigarettes to replace drugs and alcohol," noted one woman.

All the women claim to be in a very different place spiritually, since beginning Bible journaling and joining groups that do so-even if this is online, as it has been for most over the last eighteen months of the Covid-19 pandemic. Four of the women cited anxiety as an ongoing issue. Two of the women are in therapy long-term. Journaling is part of the therapy for one. Two other women belong to Celebrate Recovery groups. These are groups that may be found across the US in Christian churches. Celebrate Recovery is a 12 step programme, not dissimilar to the AA and NA 12 step programme, but it is modified, including, significantly for some Christians, an explicit focus on Jesus Christ rather than the more ambiguous and personally adaptable "Higher Power" known of in the original 12 step programme. ${ }^{3}$ The group sessions generally meet weekly around a broad range of issues that include anxiety as well as addiction. There are both large and small group sessions in these weekly meetings. The Celebrate Recovery (CR) programme includes resources such as a CR Bible, replete with added content such as testimonials, inventories and pointers to key inspirational texts, which three of the women use alongside the Bible they journal in. The motif "hurts, hang-ups and habits" is an inclusive phrase that recurs throughout the literature and language of the CR programme as it reaches beyond those who have clinical addiction issues to other emotional and psychological problems, large and small. It consciously moves the language away from the label of "alcoholic" or "addict" and recognises that addiction is complex and multifaceted in twenty-first century life. 


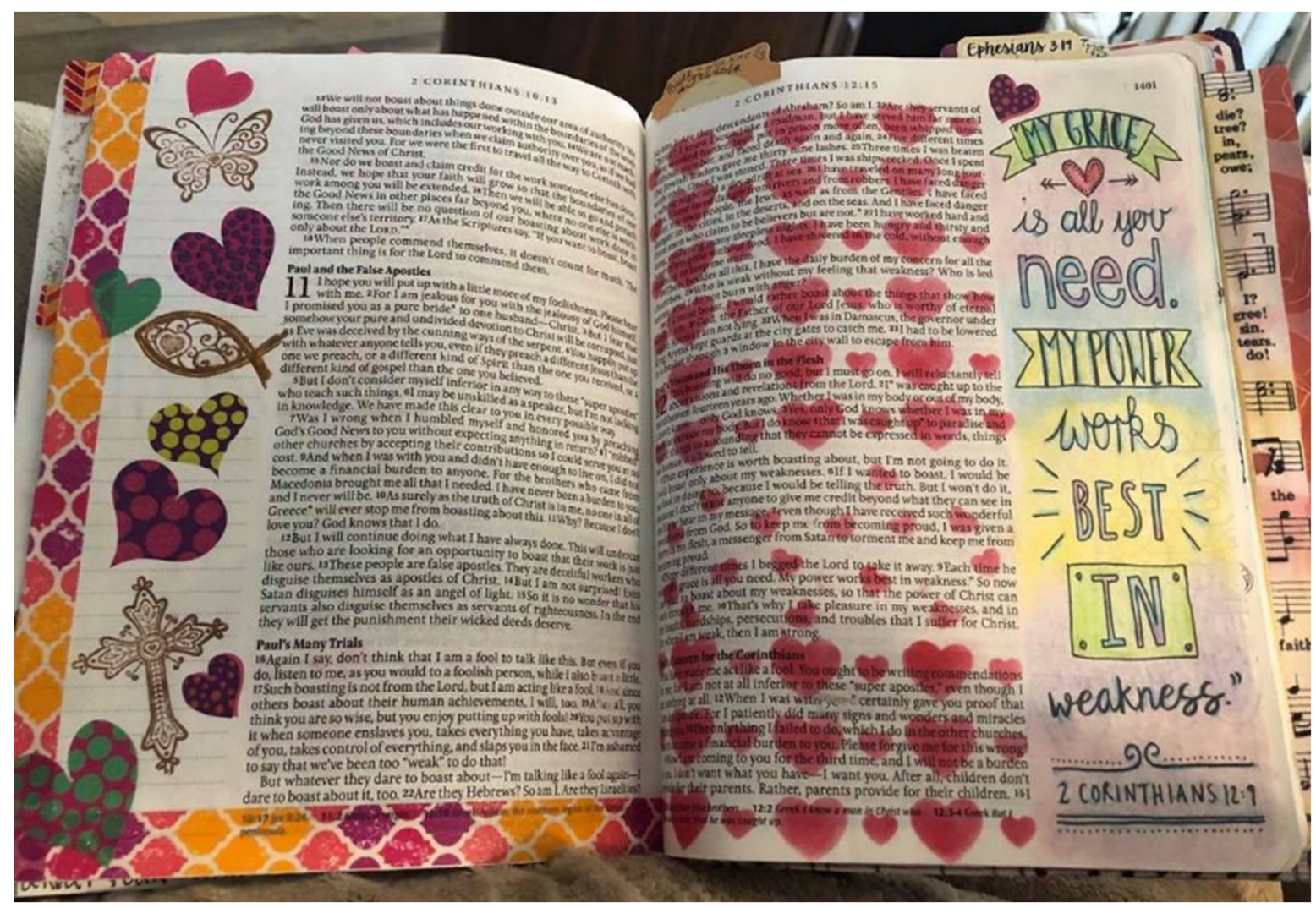

Figure 6. 2 Corinthians 12:9. With kind permission of the journaler.

Three of the women had no external intervention in their initial decision to stop their drug-taking. They spontaneously took a decision to do so having reached rock bottom, a place of desperation. Various factors played into this including the death of a dealing partner ("suicide-by-cop"), concern about their children and their role as a mother, homelessness and fear of danger. Some speak of having reached their lowest point of ultimate desperation and being afraid of dying by either accidental or deliberate overdose if they did not stop.

\subsection{Practice}

I have a few different Bible journals that I use. ${ }^{4}$ I have the Inspire Prayer, the original Inspire, the Psalms/Proverbs Illustrating Bible, and the original Illustrating Bible, and various notebooks. I usually journal every day. When journaling, it just depends, I pray around it [Bible]. I have a devotional that I use, and sometimes I open the Bible to a random page and read and then select the verses that speak to me on that day. Sometimes, I select a text from my devotional, other times it's as simple as seeing a post on Facebook with a verse that jumps out at me.

Characteristic of Bible journaling in general, the women have more than one Bible and many supplementary resources including: 30-Day Daily Inventory, Devotionals or a Faith and Focus journal. The posts of others in the social media groups can also be a launching point into a particular text. Church retreat days, Bible study or Bible conferences with a journaling component can also direct someone to a particular text. One woman writes a "daily letter to God". Another says: "I usually do mine before bed as a reflection for the day. I have a whole devotional time process though. I have a few devotionals I go through, usually they have some sort of questions attached which helps me go a little deeper and not just surface level." One makes use of being on night shift at her job. "Since I work third shift usually, I work on it while I am at work a lot of the time. It's really nice. Keeps me grounded". 


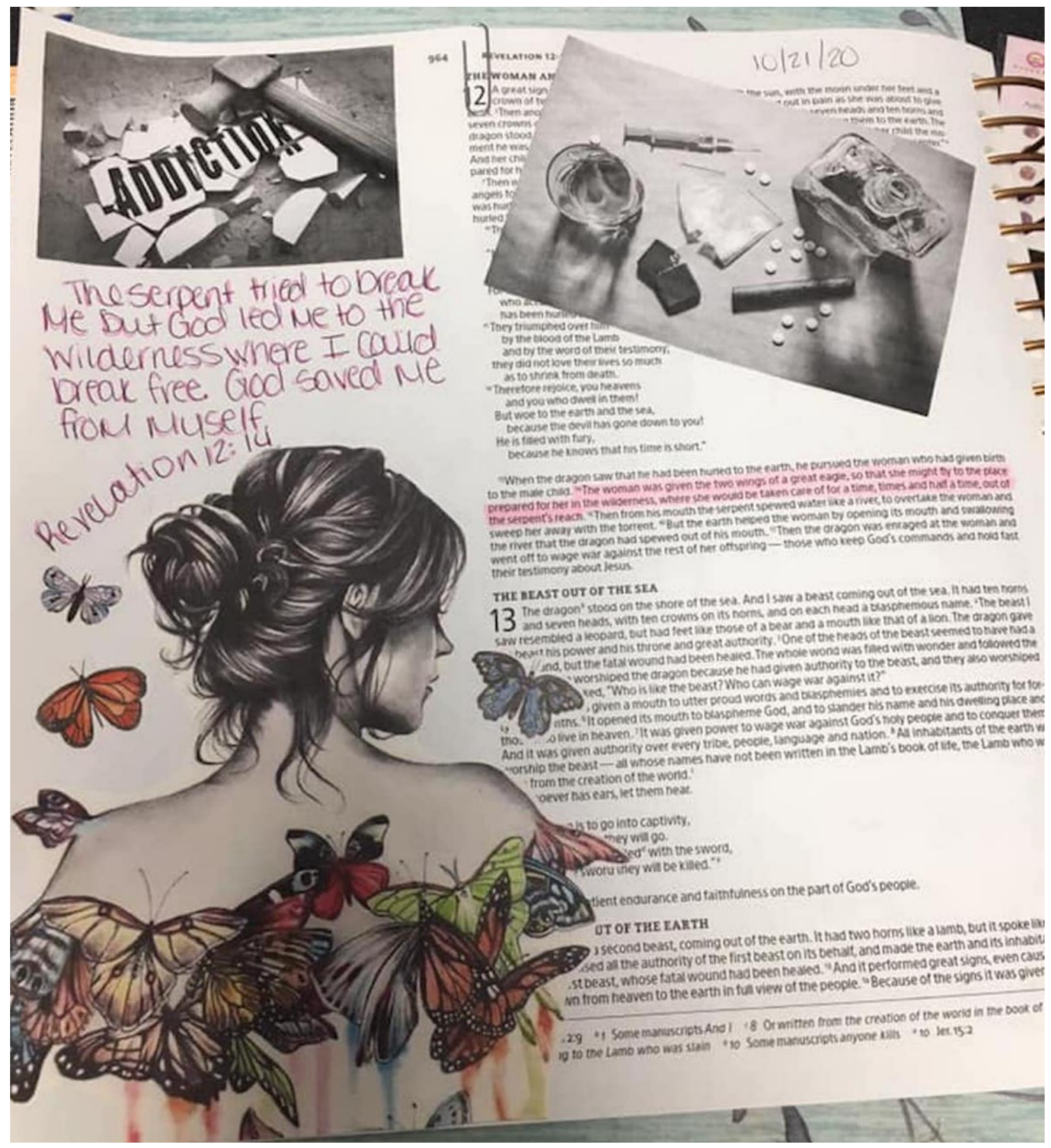

Figure 7. Revelation 12:14. With kind permission of the journaler.

\section{A Multimodal Analysis of a Bible Journaled Page}

Every one of the journaled pages that is featured in this article would make for a fascinating analysis such is the depth of reflection and quality of expression found on each respectively (Figures 1-6 and Figures 9-12). I elected to focus on the page seen in Figure 7 as it is immediately compelling on a visual level and the word-image relationship between the biblical text and the journaler's creative interventions on the page are striking for a multiplicity of reasons, as shall become apparent. 


\subsection{Thick Description}

Before launching into a detailed multimodal analysis, I would like to begin with a short thick description of what we are looking at in Figure 7. This is a journaled left-hand (verso) page in a spiral-bound, journaling Bible (NIV) with a large blank, unlined, left-hand margin. There is a handwritten date in the top right corner: 10/21/20. The biblical text featured, on the right-hand half of the page, is from The Revelation to John 12-13:14, the last book of the New Testament. Almost exactly halfway down the right-hand column of printed text, in the middle of the page, the following verse ( $\operatorname{Rev} 12: 14)$ is highlighted in pink:

The woman was given the two wings of a great eagle, so that she might fly to the place prepared for her in the wilderness, where she would be taken care of for a time, times, and half a time, out of the serpent's reach".

In the left-hand panel a black and white photographic image, one-fifth of the depth of the height of the page, has been pasted in the top left corner. It shows something resembling a rectangular white concrete block featuring the word "ADDICTION" in bold, compressed, black capitals (e.g., Helvetica Black Condensed). There is a heavy wooden hammer with a large metal head lying over the smashed lettering. Beneath this picture are six lines of text in the journaler's own handwriting clearly referring to the printed biblical text:

The serpent tried to break me but God led me to the wilderness where I could break free. God saved me from myself. Revelation 12:14.

In the top half of the right-hand column is another black and white image, pasted in over the biblical text at about a thirty-degree angle, leaning over, down to the right. This photograph, taken from above, shows the paraphernalia of hard drug use, pills, an injecting needle and so on, cast with dramatic shadows. The images used here may be sourced from magazines or the internet.

Beneath the artist's handwritten verbal text is another pasted-in image of a young woman seen from behind. This is a focal point of the page. She faces to the right-towards the printed biblical text. We see her profile. She has long hair held up in a "messy" bun revealing bare shoulders. On her naked back are an array of fifteen or so multicoloured butterflies of many different shapes and patterns and sizes. Butterflies also fly around her, and one alights on her left shoulder. A blue butterfly, flying close to the right of her face, overlaps the biblical text, as does her right side, obscuring the text. Streaks of watercolour paint bleed off the edge of the page beneath the butterflies.

\subsection{Composition}

The pink-highlighted biblical text in the middle of the printed column provides the hermeneutical key to what is happening on this page: a multimodal journaling, mixing imagery with personal, verbal text, illustrating a liberation from addiction to freedom and personal transformation. This highlighted text, working in conjunction with the handwritten text slightly diagonally above it on the left, forms a visual divider separating the top half of the page, which deals with addiction, and the bottom half, which reveals liberation and transformation. In the vertical plane, there is a polarization, a sense of contrast between the top half and bottom half of the page. In both horizontal columns, left and right, verbal text forms a visual focus between the images of addiction and the image of the young woman. This central position in a vertical arrangement has a mediating quality. That is, the pink-highlighted biblical text (right) and the personal, handwritten appropriation of that text (left), as it applies directly to the life of this young woman, function here to mediate between her former life (above) and the "new creation", her new self-image (below).

Conventionally, and historically, in artworks dealing with Christian religious content, the upper third of the format signifies the realm of the divine and the lower third the earthly domain. If we apply this structure here, this arrangement is interesting for a number of reasons. It might seem ironic or even incongruous to place these images relating explicitly 
to addiction, the very thing that may be understood to have disrupted her relationship with God, in this "divine" area of the page. Reference, directly below, in her handwritten text to "the serpent", the symbol for the devil or evil in the Christian paradigm, implies she links the drug-taking with the influence of evil in some way.

Moreover, the opaque image on the right is placed directly over the biblical text. If we understand the scriptures as a foundational place of encounter with God for the reader, it follows that one potential meaning to this placement of the crooked, right-hand image is that the elements it features obscured and prevented her reading of the Bible, representing a disruption in her relationship with God. This drug habit formed a barrier between the artist and God.

The angle of the right-hand image is also significant. Considering first the elements within this photograph, it is worth noting that none of the items in the image are aligned with either the vertical or horizontal axis. Every element is at a slightly different diagonal angle and slightly differently angled from each other object. Only the injecting needle and the pipe show any consistency in their parallel arrangement. The placement is apparently random. By contrast, a highly ordered layout would conform to the grid of vertical and horizontal—one might expect this in a photograph of medical implements for a scientific journal, for example. Diagonals within a composition may enliven an image with dynamism, movement and energy but may also allude to disorder and dysfunction. That this image is then placed on the page at an angle reiterates the instability implied in the internal composition. Here,-at a downward-tilting 30-degree angle, unbalanced, not on an even keel, falling - even this slanting of the picture speaks to the disorder that the elements figured brought about in her life.

The placement of the addiction images in the upper third suggests that what they represent for the journaler is not in the down-to-earth realm of the journaler-where she has placed a representation of herself. Addiction has been placed in another realm, the divine realm. In other words, we might say, in the everyday discourse of Christian spirituality that this problem has been "handed over to God", that former drug-taking is now in the control of God and no-longer in her realm of reality. She is separated from it by the mediating biblical text, the Word of God that speaks of God's intervention in her life, which she has appropriated for herself. This is further confirmed in the past tense structure of the handwritten text.

The two addiction images are contained within rectangular boxes, with clearly defined, sharp edges. They are bounded. By contrast, the image of the young woman, larger than both, is not contained, but bleeds off the edges of the page to left and bottom and over the biblical text on the right. In keeping with the freedom it signifies, it is an expansive, organic, free shape reaching into the space around it, with further individual butterflies flying about, freely overlapping the text. It is a powerful, mystical and highly symbolic image. Moreover, great salience is added here in the bright colouring of the many butterflies, adding to the foregrounding of this image, as does its overlapping of the text. The bright colours not only illuminate the butterflies but also form a rainbow of sorts, running "down her back" off the page into space, flowing out into her life.

Human nakedness, in the context of the Bible, carries strong connotations of the creation narratives of Genesis (the opening book of the Bible). Her naked shoulders allude to new birth, emergence and freedom. There are many connotations one could assign to this illustrated figure in relation to the Bible. In her nakedness and surrounded by, arising even, from the vibrant, flowing, living beauty of nature, she may be seen as a type of Eve, in the positive sense of being an original creation of God, at home in the Edenic garden, before the Fall. In the New Testament, Paul makes reference to "a new creation": "So if anyone is in Christ, there is a new creation: everything old has passed away; see, everything has become new!" (2Cor. 5:17; and see Gal. 6:15). The sense of arising out of a kaleidoscope of butterflies links the women closely with the butterflies, she is a metamorphosed "butterfly" too. The flutter of butterfly wings picks up on the mention of wings in the highlighted text; the woman was given "wings" (of an eagle), and here is a woman with many wings. 
The journaler herself says, "The butterflies symbolise the addiction leaving my body and becoming beauty in God's Grace".

The symbolic value of the butterfly in Christian art is closely linked to transformation. "A dual symbol whose short life and transcendent beauty signified vanity and futility, but whose three-stage cycle as a caterpillar, chrysalis, and butterfly denoted resurrection or new life. The chrysalis was interpreted as a symbol of sleep or death and the butterfly the new life that arises out of sleep or death. When either the Christ Child or his mother held the butterfly, it connoted the Resurrection" (Apostolos-Cappadona 2020). Within the Greek symbol system it represents the soul and its personification, Psyche (Hall 1994).

This pose of the woman is important here. Turning, both the bodily gesture and the mental disposition of shifting focus, is an enduring trope of the Hebrew and Christian scriptures. The verb "to turn" indicates a shift in understanding, behaviour, attitude and direction, sometimes simultaneously both psychological and physical. It may also include a radical transformation in material form brought about by God: Lot's wife turned to look back and was turned into a pillar of salt (Gen. 19:26); in Exodus, the plagues include the waters of the Nile River being turned into blood (Ex. 7:17, 20). Turning often signals a change in the narrative. Repeatedly, one hears of God "turning" attention and favour, or anger, towards or away from individuals or nations (Deut. 23:14; Num. 25:11; Judg. 4:2;). Prophets urge the people not to "turn" to idolatry (Lev 19.4, Deut. 11:16); travellers "turn" and set out on a journey (Gen. 18:22; Deut. 2:1); Moses "turns aside" to behold the spectacle of the burning bush (Ex. 3:3). The natural elements are subject to God's turning action: "and the Lord turned a very strong west wind" (Ex. 10:19). The New Testament continues the prophetic call to turn away from wrongdoing and turn towards the Lord (Matt. 18:3; Luke 1:16; Acts 14:15; Acts 26:18; Acts 26:18; Gal. 4:9). Again, as with the OT, turning is also linked with radical, material transformation brought about Jesus, such as the turning of water into wine at the wedding at Cana (John 2:9). In the journaler's choice of this illustration of the young woman, representing herself, she is indicating two different aspects of turning. Firstly, she has turned away from, turned her back on her previous life. Secondly, her head is turned towards the right and now looks towards the biblical text, the Word of God. There has been a fundamental change in her life, in her direction, away from a former way of life towards a new spiritual engagement with her God. This turning signifies radical psychological, spiritual and physical transformation.

In a semiotic analysis of the visual elements it is important to note the two different perspectives offered in the images used here-both of which further demonstrate the meaning-making at play. The two black and white photographs show their objects from directly above. This is referred to as the "bird's eye view" or interestingly, in this context, "god's eye view." This is an objective observation of the elements or situation, from a privileged position of power or authority. "It contemplates the world from a god-like point of view, putting it at your feet rather than within your reach of your hands" (Kress and van Leeuwen 2021). Again, this both reinforces the suggestion that the upper third is the realm of the divine on this creative construction. Mostly importantly, it also implies that the journaler herself shares this viewpoint and is able to "look down" upon these instruments of addiction from an objective standpoint, and from a position of both power over and detachment from her previous life.

When we turn to the illustration of the young woman, there is a marked change in perspective. The viewer is placed "on a par" —at the same "eye-level" as the woman illustrated here-in what is referred to as the close personal range, featuring the head and shoulders, indicating a high level of identification with the woman figured. Again, there is a high level of modality in terms of realism here, even though it is a conceptual, symbolic image. The black and white establishes a visual link with the images in the upper realm, but the addition of vibrant colours raises its salience and heightens the symbolic value of a coming to new life, a transition from the world of the black and white, the former life in addiction, blooming into the world of full colour, in this immediate and personal time and space. 
Likewise, the modality of these two images is significant. Both are photographs suggesting a high-level of modality, in the sense of representing reality or "truth". They are not abstract, although the image on the left is conceptual rather than an image readily drawn from real life; it is contrived albeit looking very "realistic". The image on the right, may be said to have an almost analytical, scientific diagram feeling about it, systematically setting out the various items related to drug misuse; it could almost be labelled and featured in an educational resource explaining the function of each item. Again, I suggest that this high-level of modality demonstrates that the journaler has no illusions about this reality of this dimension of her past.

I suggest the mode of black and white photography here serves to add a temporal dimension. Black and white photography is indicative of a bygone era, BC-before colour. Potentially, it also hints that whatever colour, fun, bliss, vibrancy that she may have once experienced in this way of life has faded, has dissipated, and been replaced with the cold, hard facts. There is no romance about this static image. It is an image from another time demonstrating a further distancing of the self from this previous reality.

\subsection{The Word-Image Relationship}

\subsection{1. "Break"}

The woman was given the two wings of a great eagle, so that she might fly to the place prepared for her in the wilderness, where she would be taken care of for a time, times, and half a time, out of the serpent's reach. (Rev 12:14)

As the pink-highlighted text is a particularly rich sentence of Scripture, it is worth spending some time opening up its meaning and the profundity it therefore lends to this page of journaling as personally appropriated by this journaler.

Above this picture of a woman is her own handwritten reflection: "The serpent tried to break me but God led me to the wilderness where I could break free. God saved me from myself. Revelation 12:14".

This is a striking sentence that mediates connections between the picture above it and that beneath it, as well as the focal sentence in the biblical text. It almost paraphrases the parallel printed text. It is also written more than once, in the same place, layered initially in pink, the same colour as the highlighted biblical text, making an explicit link visually between these two pieces of verbal text. It is then repeated, reinforced with a stronger, darker colour. The repetition highlights the importance of this reflection for the journaler. The word "break" is used twice here. Firstly, it refers to the action of "the serpent" upon her; secondly, it refers to her own action as being able to "break free". Again, in the first instance it appears directly beneath the image of the broken word "ADDICTION", the attempt of the serpent to break her through addiction, but she prevails and breaks free of the addiction. The placing of this handwritten text here directly correlates with the image above it, in a powerful multivalent way. This liberation is attributed to God who led her "to the wilderness" and who "saved" her from herself. The image is placed on the right up in the divine realm of the page, reiterating God's saving action.

\subsection{2. "Wilderness"}

The use of the deeply symbolic word "wilderness" occurs in the Rev 12:14 text too, described as "a place prepared for her, where she would be taken care of, out of the serpent's reach". This sentence is rich in the language of providence and loving, protective care. Virginia Burrus emphasizes in her exegesis that the woman is protected by the wilderness, which "cradles her body" (Burrus 1999). In the Bible, the wilderness is a complex tropeboth a place of danger but also one of potential safety and provision. Leonard Thompson suggests that "wilderness" functions in Revelation "symbolically as a place similar to chaos with transformational potential for judgment, deliverance, nourishment, punishment, death, and rebirth" (Thompson 1997). "In Revelation place is bound up with destiny and contingency" writes Schüssler Fiorenza (1991), and Brian C. Jones points to the liminal aspect: "wilderness denotes both a place and an existential condition. It is a zone of 
liminality where individuals or groups encounter existential limits and where they are tested and transformed through numinous encounter (Oropeza). For humans, wilderness is a passageway, not a destination" (Jones 2009). Writing about this text, biblical scholar Yarbro Collins says the purpose of the story is "to interpret the present situation of his [the author's] first readers and to encourage them to take a particular stand. [ ... ] The most illuminating way to read the story is as a paradigm or model of and for the experience of the first readers. They are expected to identify with the woman [ ... ] The rescue of the woman evokes trust that these hardships are not in vain" (Yarbro Collins 1979). In other words, the journaler here has done exactly what the author intended and read herself into this text.

The manner of rescue involves themes from the exodus story. The two wings of the great eagle recalls a traditional metaphor for the deliverance from Egypt-"You have seen what I did to the Egyptians, and how I bore you on eagle's wings and brought you to myself" (Ex 19:4). The refuge taken in the desert calls to mind the wilderness wandering. In John's time, retreat to the desert symbolised readiness for the manifestation of God's rule. This figurative account of rescue does not necessarily imply literal protection from harm. In the context of the Apocalypse as a whole, it expresses a radiant trust in divine providence even in the midst of hardship and suffering. (Yarbro Collins 1979).

The eagle is a symbol of God's providence in Exod 19:4, Deut 32:10-12. "[God] enables her, like the children of Israel to reach the desert, which in both the OT and NT represents a place of provisional safety, of discipline, of waiting for the promises of God. It was thus in the Exodus period for the forty years before the Israelites entered the promised land; $\mathrm{cf}$. Deut 8:2-10." Twice Elijah withdrew to the desert; 1 Kings 17: 2-3, 19:3-4. Yahweh lured his bride into the desert; Hosea 2:14. Isaiah commanded a highway to be made for the Lord there; Isa 40:3. The bride in the Song of Songs is said to come from the desert; Song 3:6-8, 8:5 (Massyngberde Ford 1975).

It is in the wilderness that John the Baptist prepared himself and the people for the Coming One (Luke 1:80, 3.2). In the synoptic gospels, following his own baptism, Jesus is led or driven out into the wilderness, by the Holy Spirit, as he prepares for his public ministry (Matt. 4:1; Mark 1:12; Luke 4:1).

\subsection{3. "Nourish"}

In other Bible translations (NRSV, ESV, KJV) the word "nourished" may appear in place of "taken care of". This also echoes previous occasions in which God nourished those in the wilderness: the Israelites are nourished with manna in the desert (Ex. 16:31-35; Num. 11:6-9; Deut. 8:3, 8:16; Josh. 5:12), as is Elijah (I Kings 17:4, 19:5, 7).

\subsubsection{Conclusions}

The belief of the journaling artist here is in this providential care and protection of a loving God who led her to "the wilderness" creating a "prepared place" in which she could break free from the hold addiction had on her life. As is seen in these previous instances of reference to the wilderness in the Bible, it is a liminal place of both provision and preparation. It would be safe, I suggest, to interpret this here as an acknowledgement, on the part of the journaler, of an experience of liminality in her recovery and of recognising this as having been a safe space of provisional care brought about providentially by God.

It is clear that this page illustrates profound personal transformation away from drug addiction and into a new, liberated life. The journaler has brought many different elements, both realistic and conceptual, to a page of biblical text, one sentence of which, laden with resonance, she has appropriated to her own life and woven into a beautiful, sophisticated, deeply personal, multimodal narrative describing God's liberating and salvific action in her own life. 


\subsubsection{And Then}

In response to my request for the high-resolution image for the purpose of this publication, the journaler kindly sent the photo. However, it came with further additions to the page-something I had not expected-but, of course, within the context of this multimodal analysis proved fascinating and heartening. As you will observe on Figure 8, three further butterflies have been added to the page. They all appear on the right-hand side overlapping the printed biblical text. Several interesting factors may be observed here. Firstly, the butterflies are larger than those on and around the woman. Secondly, they overlap the biblical text but do not obscure it completely as they are semi-transparent. They do not, however, overlap or obscure the pink-highlighted text. It may be that the journaler has internalised this text, having appropriated it so intimately to her own journey, memorised it by heart and so can call to mind those words that may be obscured. It may also be indicative of emboldened spiritual autonomy taking flight and vigorously embossing her newfound inner strength and renewed sense of identity fully across the page, across her life.

I suggest the yellow central butterfly acts as a further pointer, drawing attention to this line of text. Thirdly, the highest of the butterflies on the page, has crossed over the former dividing line, as it were, of the pink-highlighted, printed text, into the upper realm. This butterfly almost touches or overlaps the bounded, rectangular black and black photograph, but does not. In other words, what is signified by this photograph remains firmly contained, sealed within that frame. This butterfly now sits prettily alongside her handwritten text, and as it is slightly pinkish in colour, makes a further visual link between the two pieces of verbal text, left and right. What is most significant about these additional butterflies, however, and closely tied to their increased size, is their texture. They are embossed butterflies made out of a type of plastic or silicone gel. These butterflies are not two-dimensional, but three-dimensional, they have form. This is a firmer, stronger, more durable material. One could trace the contours of the margins of the wings and the antennae. And we might trace this progression from the flat, flimsier, paper butterflies to the gel-embossed butterflies as marking an advance in the artist's strengthening confidence in her own recovery. As the butterflies fan out across the page, larger and more robust in material, in character, one intuits an ever-greater sense of blossoming, flourishing and freedom from the journaler. The energy of transformation is dynamic and expanding, taking up more space, with greater vigour, becoming the decidedly dominant feature on this page. The metamorphosis denoted by the butterfly symbol and its implications for her spiritual journey of recovery continues positively. 


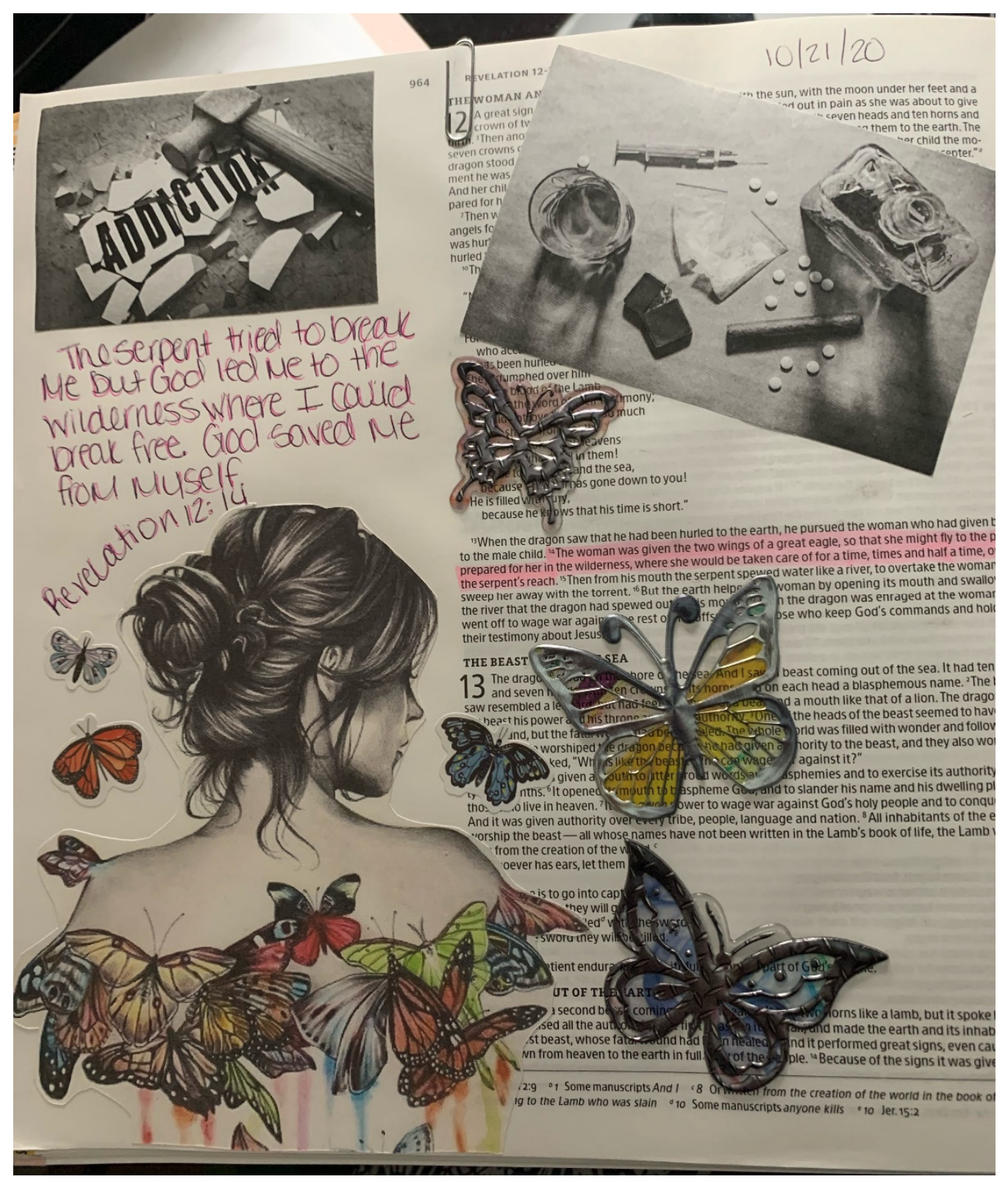

Figure 8. Revelation 12:14. With kind permission of the journaler. 


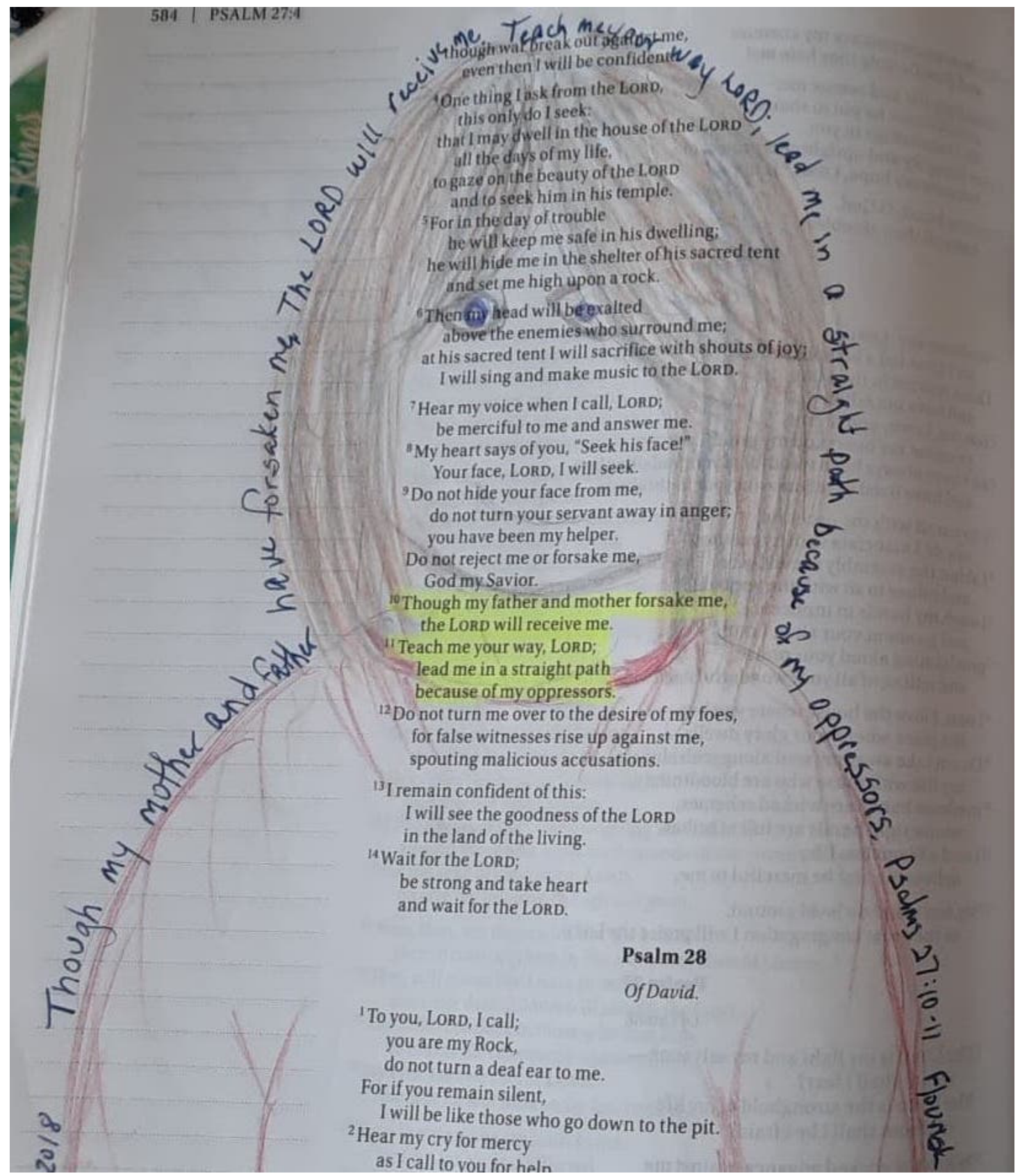

Figure 9. Psalm 27:10-11. With kind permission of the journaler.

\section{A Necessary Note on Trauma and the Bible}

It is important to acknowledge that trauma lies at the root of addiction for many people (Maté 2018; Etherington 2008; Alexander 2008). One may add to this that addiction itself may be experienced as a trauma and often brings further trauma into the life of an addict. Furthermore, scholars recognise the multiple catastrophes or impending catastrophes, be they natural disasters, war and migration or financial collapse, and add to that a global pandemic, political insurrection and further climate-change related environmental crises, as constituting our contemporary time as a "trauma paradigm" or "trauma culture" (Andermahr and Pellicer-Ortín 2013). Among those interviewed, a number referred to traumatic events: the death by suicide of a partner, overdose, homelessness, abusive parents or partners, to mention a few examples. Many also referred to experiencing high levels of anxiety on a day-to-day basis. What role might the Bible play in assisting the recovery from trauma? 
Within Biblical studies, trauma studies has now become an area of interest and interdisciplinary research. According to Claassens, "Given the fact that ancient Israel found themselves repeatedly invaded and occupied by one empire after another, much of the biblical literature that emerged from Israel's traumatic past can thus be characterised as trauma literature" (Claassens 2020). The collective trauma experienced by the people spurred the prophets (such as Jeremiah) to write with the intention of making meaning out of their suffering for the traumatised people (Stulman 2014). "By means of poetry, throbbing with raw emotion and pain, as well as a number of narratives, reflecting multiple layers of trauma and suffering, the authors of the prophetic books sought to capture something of the violence the community had lived through" (Claassens 2020). This understanding of the biblical text as a type of "trauma literature" suggests it may offer the contemporary reader a narrative holding space in which to reflect upon their own trauma and contemplate God's response and care for individuals and nations in these situations. Already, we have seen how one apocalyptic passage (Rev 12:14) offered a meaning-making textual mirror for one recovered addict. There is, however, a flip side to this appreciation for the affirming dimension of biblical narratives, of which one has to remain vigilantly mindful. Equal to the recognition of this beneficial aspect, is an increasing critique of the abuse of the biblical text by undereducated and unloving pastors, church workers and believers. No doubt the Bible has always been manipulated to suit agendas, often antithetical to its driving message, in order to bully, stigmatise and, one may even go so far as to say, traumatise people. One only has to think of so-called gay-conversion therapies to know that there are victims of such abuse who would no doubt describe themselves as traumatised by certain interpretations and presentations of the Bible (Ó Tuama 2015). Gender is another area where misogynistic interpretations of women's value and role in family, church and society are recognised as causing profound emotional pain for many women in the church. In some denominations, these constructs purportedly drawn from the Bible, carry the monikers "Biblical Womanhood" and "Biblical Manhood" (Barr 2021; Byrd 2020; Kobes Du Mez 2020). One of the women in this study spoke of how journaling, including Bible journaling, is helping her work through her childhood experience:

I believe journaling is God answering my prayers and showing me the answers he wants me to have. It is calming for me. My therapist has me journal everyday. Even if all I write is 'life sucks', 'I wanna smoke', 'Anxiety is high', 'Pain hurts', etc. It is me being real with where my thoughts are. My therapist and I have been able to uncover lies I believed ... such as because I was not a boy I was unlovable by God. Because I wrote my thoughts. Then she helps me change the lie with Scripture. It's a long process but one I'm willing to do ... must do in order for whole wellness.

She has helped me heal a childhood where my Sunday School teachers told me regularly I was "Satan's child" ... where my twin brother was the perfect child. Boys were the chosen ones in what I grew up with. It contributed to my addictions to numb the feelings.

Valuing the Bible as a spiritual resource for healing from addiction or emotional pain carries with it the parallel necessity of knowing that it is also used to cause emotional pain and trauma.

\section{Limitations to This Study and Future Directions}

There are a few notable limitations to this study. Firstly, the size of the cohort is restricted to five participants. Clearly, the potential for a larger sized cohort is available but would require greater resources and capacity. The highly personal nature of an inquiry into the intimate life stories of people who have suffered from addiction, and all the negativity that invariably brings into one's life, requires a great deal of awareness, planning and care for the protection of people's privacy and respect and concern for their vulnerability throughout the process. Secondly, only one journaled page is given a thorough multimodal 
analysis. An analysis of a page of each of the three journalers' submissions, to this study, would profoundly enrich the investigation. It would allow for more concrete assertions about the value of Bible journaling as a spiritual resource in this very particular context of addiction. Finally, this article has focused on an in-depth multimodal analysis and has demonstrated the value of this methodological approach in drawing out the meaningmaking processes at work, in this fascinating reception of a text by a Bible reader and her interventions on the page in response to that. This approach foregrounds the criterial choices made by the creator of the multimodal artefact, allowing them to "speak" for themselves. An interesting further step might have been the inclusion of one or more art therapists in a discussion around their perceptions of the featured page or pages. Would they, approaching the pages with a different disciplinary (psychology) framework, arrive at similar or different analyses of the expressive content displayed?

Noting these limitations immediately opens up potential directions for further research. Multimodal analysis places the creator's productive meaning-making choices at the centre of its enquiry. It provides the scientific discourse for a thorough semiotic analysis of a semiotic event or artefact. It allows for both an in-depth analysis of one item, such as the page analysed here, or a broad analysis of multiple items of similar significance. A large scale meta-analysis into multiple pages of Bible journaling in this context of addiction would allow for the cross referencing of the choices of biblical text, the visual treatment of the biblical text (highlighting, accentuating, obscuring, etc.), the choices of key symbolic tropes (i.e., butterfly), the treatment of human figures, the representation of the "self" in some way, the addition of further text (by hand or pasted in), free drawing and use of imported images (drawn by other artists and sourced online, in magazines, etc.), the representation of the divine, the representation of addiction, the modality of colour, composition, scale, texture and point of view. It is my firm contention that multimodal analysis has much to offer those working in the spiritual and psychological care of people with addiction issues as a resource for understanding the self-expressive, multimodal communication of people who journal. 


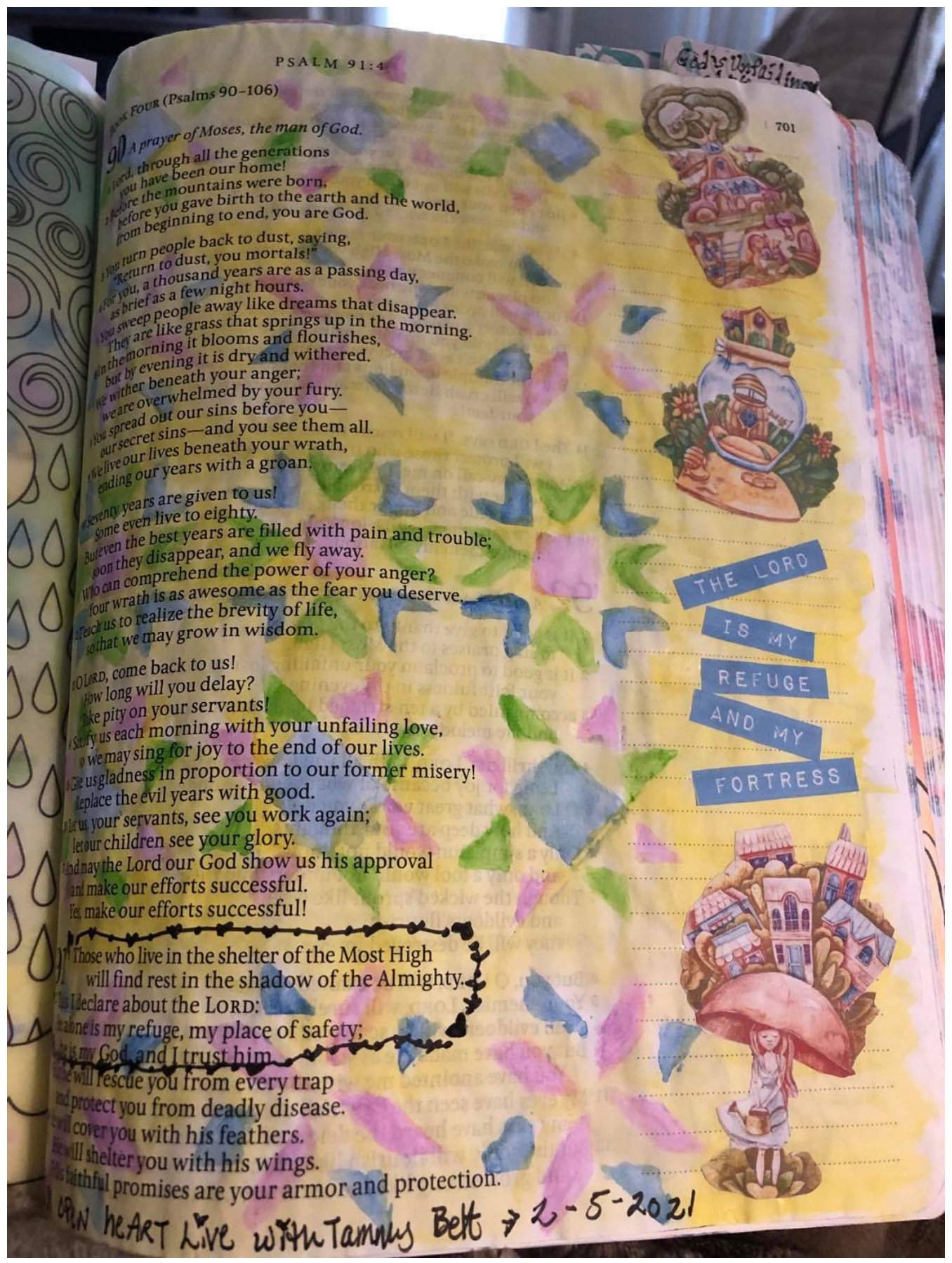

Figure 10. Psalm 91:1-2. With kind permission of the journaler.

\section{Conclusions}

Our images reveal that we are holographic creatures, living multiple stories.

(Allen 1995)

In one respect, the Bible journaling phenomenon is a consequence of the expansive US Bible publishing business that is constantly looking for new ways to market the Bible. Whilst initially intended for written journaling, it has developed in unexpected ways due to the ingenuity of readers. Many of the techniques journalers use may be recognised as having possibly originated in the multimillion-dollar scrapbooking and colouring hobbies that have preceded it. The mass marketing of Bibles in the US has also meant the individual ownership of multiple copies of the Bible and therefore a different approach to the material 
book (Beal 2012). Nonetheless, it may be argued that the journaling readers have set the course for these Bibles and new iterations are a response to consumer demands (wider margins, thicker paper, spiral binding, etc.). Such is the interest and momentum in Bible journaling, it is difficult to see it waning anytime soon as a significant spiritual practice for a large number of Bible readers.

Observing the importance of this practice for those who engage in it, one wonders how this might be relevant to other religious groups in relation to their sacred Scriptures and holy books. Dillon (2020) has shown that Jewish and Muslim journalers are slowly yet increasingly involved in journaling with their sacred texts but in a markedly different way, in that they journal alongside their holy book in a separate journal and not directly into and on the pages of their holy books. Interventions directly in the material book of Scripture would not be acceptable in these faiths. Nonetheless, very beautiful pages featuring, for example, calligraphic treatment of an individual ayah embellished with arabesque or floral designs may be seen in the work of Muslim journalers of the Quran (Hassan 2016). Jewish and Muslim journalers are also more circumspect in the public sharing of their journaling. Within online Christian-dominated Bible journaling groups there are a very small number of journalers who identify themselves as Jewish and share their work. However, it is difficult to discern, as yet, groups with a distinctly Jewish leadership, membership and Hebrew Bible focus. With regard to Muslim journalers, these social media groups are generally not publicly open and are more controlled in terms of membership.

The plain journal market is one that continues to develop and expand. Plain journals with well-designed covers featuring the Om symbol, Sanskrit texts and graphic designs and artwork from the Dharmic religions are available. I suggest it should be possible to develop dedicated journals with selected texts from the Scriptures of other faiths, as features within the journal and focus points for contemplation and reflection in written or visually creative form. Indeed, journals of this type may already be available in regions where these religions are practiced and be used in similarly creative ways.

As the journaling of biblical texts has proven to be of great support to those in recovery from addiction, and other mental health issues such as anxiety, I suggest that adherents of other religions struggling with or in recovery from an addiction would likewise find spiritual support, inspiration, courage, strength and benefit from a similar journaling practice with their own venerated texts.

As one woman mentions, her therapist uses Bible journaling as one means to work with her client in reframing negative childhood messaging she received from her church. In some contexts, this approach might be deemed to belong to the realm of spiritual direction rather than professional therapy. Spiritual directors may well decide this practice would beneficially suit certain directees. Those who use art therapy would be well served by some knowledge of multimodal analysis and the social semiotics of visual expression.

In Bible journaling, many women find a spiritual practice that supports them in their recovery from addiction and the establishment of a new self-image. Through Bible journaling, these women contend with their pasts and acquire a new status understanding themselves as forgiven and loved by their God and supported through God's promises in Scripture. Their pain is assuaged, losses faced and a new future heralded. The foundational text of their faith is engaged with in a very tactile and immersive way: keywords reiterated in stickers, letters cut from magazines, naive drawings and pencil-crayoned self-portraits alongside highlighted verses, weaving images and words together in a newly wrought interpretation that speaks directly to their particular situation. Through this practice, many women take what was and what never was and create what is "me", "a new creation" (2 Cor 5:17) able to carve out a new life and cope with the challenges of living.

Bible journaling emerges, in the last five or six years, as a new contemplative and reflective practice, performed almost exclusively by women. Through this creative engagement with their holy Scriptures, women become first-hand receivers and interpreters of these texts, in the private domain of this personal devotional reading and creative intervention. They become the first interpreters of a divine word spoken to them and internalised 
through this lengthy and elaborate, creative engagement. This practice generally happens either individually, or in small groups of women, and is shared in online groups that are likewise almost exclusively female. In other words, this is biblical interpretation and appropriation happening beyond and outside of the often highly controlled, patriarchal and male-clerical space of the organised religion of Sunday morning. These women are becoming authoritative readers and interpreters of their own Scriptures. This is profoundly significant and, I contend, must have enduring consequences for their mental health, their lives, their families and their churches as they develop spiritual autonomy in relation to, and with, their holy texts.

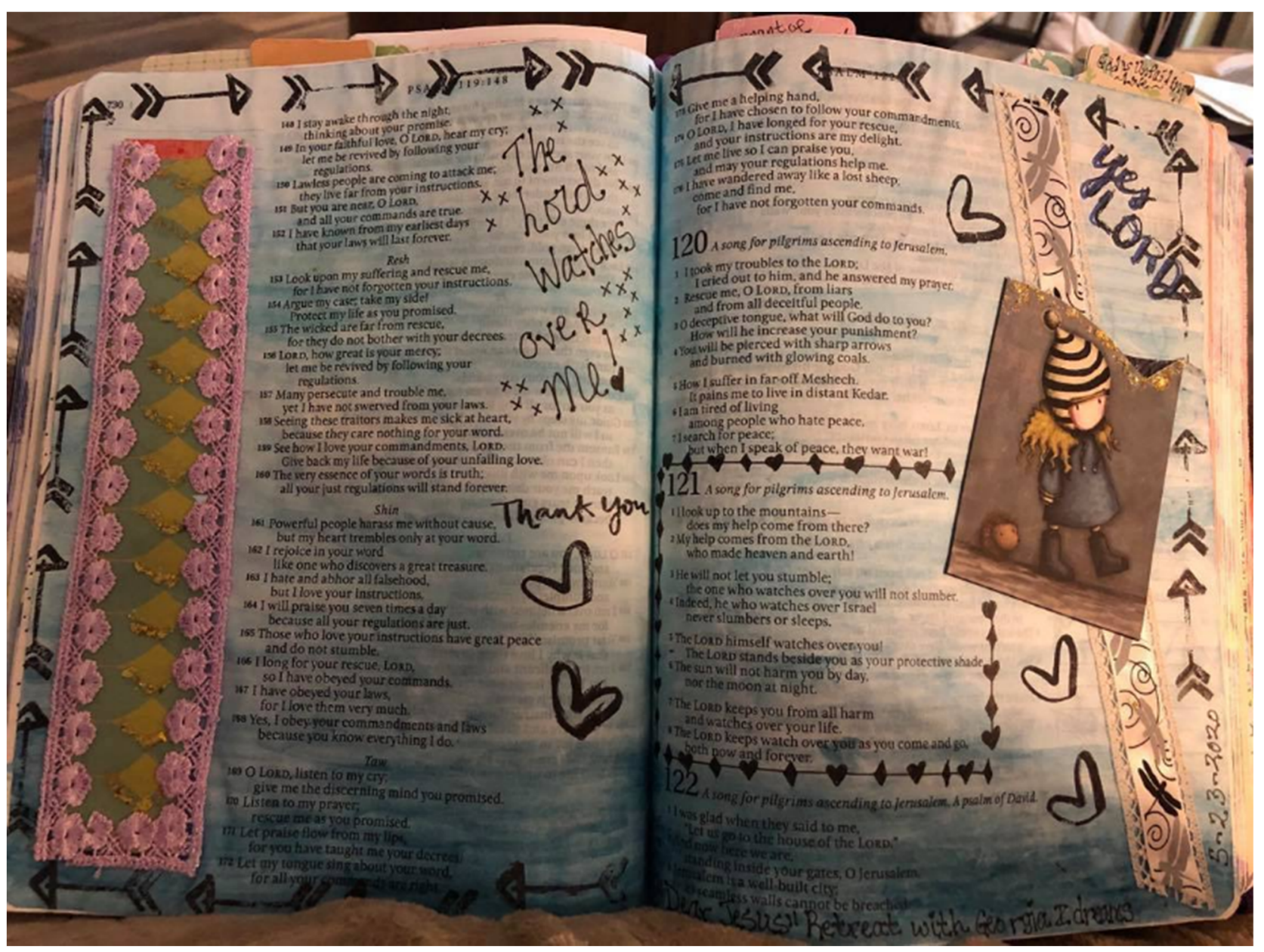

Figure 11. Psalm 121. With kind permission of the journaler. 


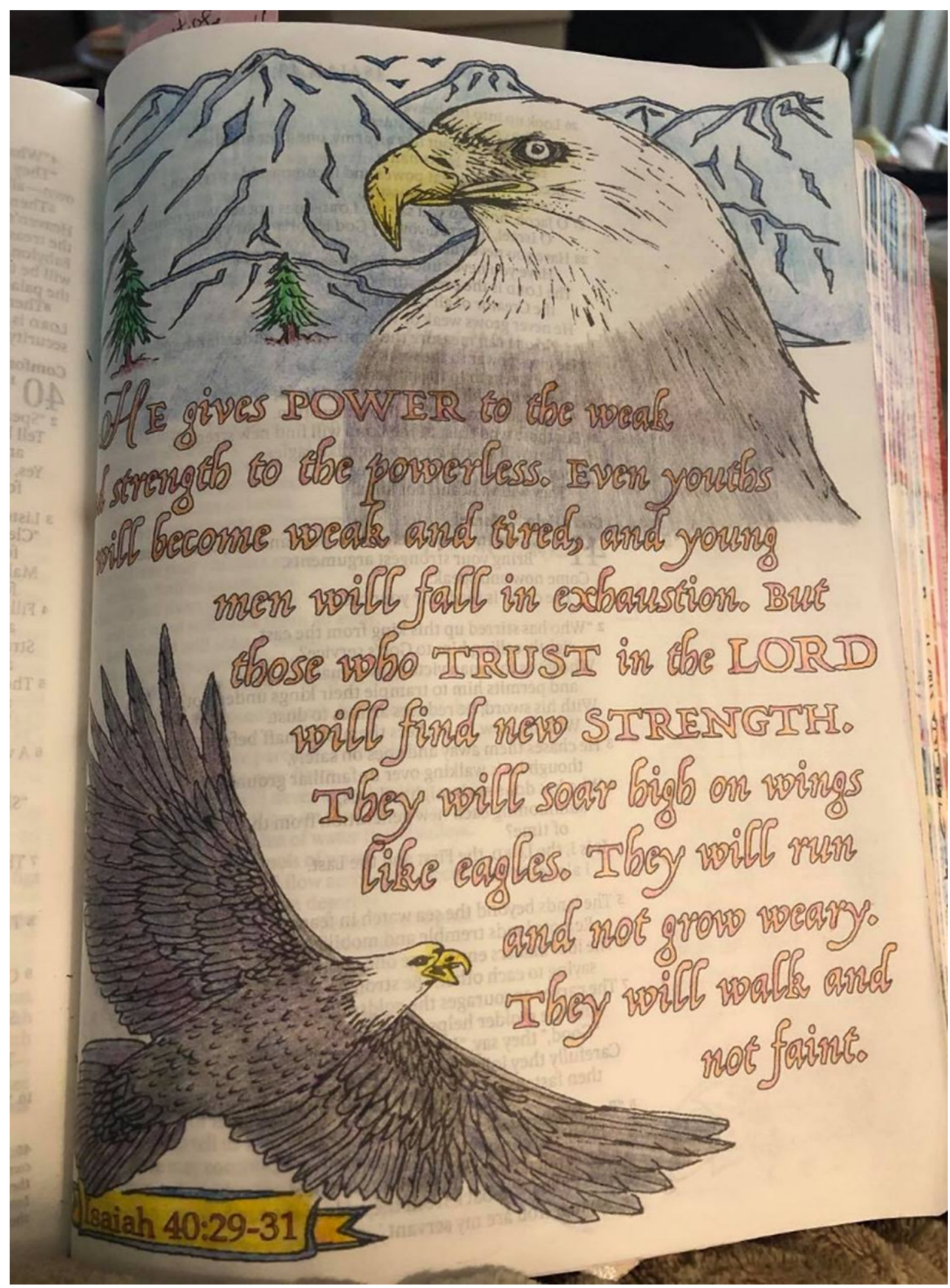

Figure 12. Isaiah 40:29-31. With kind permission of the journaler.

Funding: This research received no external funding. 
Institutional Review Board Statement: Ethical review and approval were waived for this study, due to the methods being applied complying with professional reflective practice analysing images. No new interventions or artworks were created in the course of the research conducted.

Informed Consent Statement: Informed consent was obtained from all subjects involved in the study.

Conflicts of Interest: The author declares no conflict of interest.

\section{Notes}

1 The Bible, as it exists today and is named and discussed in this article, consists of three parts: the Hebrew Bible, the Apocrypha, and the New Testament. The Hebrew Bible or Tanakh contains the canonical collection of Hebrew Scriptures, including the Torah ("Teaching"), Nevi'im ("Prophets") and Ketuvim ("Writings"), composed between roughly 900 BCE (possibly later) and 160 BCE in Hebrew or Aramaic. The Hebrew Bible shares much of its content with its ancient Greek translation, known of as the Septuagint. It is important to note that these texts predate the emergence of Christianity and the Christian writings of the first and second centuries CE. The Hebrew Bible is also venerated by Christians. It came to form the first and larger part of the Christian Bible and is referred to as the Old Testament, in the Christian Bible. Within Christianity, the Roman Catholic church, Eastern/Greek/Ethiopian Orthodox churches and some Protestant churches recognise and include varying numbers of additional books as belonging to a second division, within the OT, named the Apocrypha. There are many differing traditions across denominations and religious groupings concerning which books belong in the canons of Scripture. The New Testament consists of 27 books. It was composed and redacted over a period of about a century, by diverse authors, in Greek, between about $40 \mathrm{CE}$ and $140 \mathrm{CE}$. It was recognised as a canon of Scripture formally in the Christian church in the fourth century. The Bible contains texts recognised as divinely inspired by adherents of Judaism, Christianity, Islam and other faiths.

2 Percocet $30 \mathrm{mg}$. Percocet is a medication used to help relieve moderate to severe pain. It contains an opioid pain reliever (oxycodone) and a non-opioid pain reliever (acetaminophen).

3 The 12 step programme has many strong advocates within the addiction recovery literature, including from those who vouch for it enabling spirituality to be factored into a holistic approach to and for the person in recovery (see Plante 2018; Rohr 2011; Ringwald 2002). Others, however, are critical of this method and how the spiritual dimension is dealt with (see Szalavitz 2019).

4 Bible journaling has proven extremely lucrative for the publishing industry. Almost every US Bible publisher now offers many versions of a journaling Bible. Many popular translations are available as a journaling Bible, including but not limited to CSB, ESV, GNT, NAB, NIV, NKJB, NLT and NRSV, and where relevant, include Catholic editions. Some publishers have a multiplicity of versions, packaged in a variety of formats, targeted at different demographics. Some publish selected books of the Bible, such as the Psalms and Proverbs, separately. Journalers' choices are made based on both preferred translation as well as the attractiveness and functionality of the book design. Comparing and contrasting these many different translations and editions are frequent topics of discussion in the many dedicated social media groups. Many journalers have more than one Bible journal 'on the go' at any one time, sometimes preferring one translation of a particular text over another. Some journal a Bible as a gift. One woman, not included in this study, was journaling her journey through drug addiction recovery as a legacy she would be handing on to her children in time, in order that they might understand what she been through and how these texts had shaped her recovery.

\section{References}

Adams, Kathleen. 2004. Scribing the Soul: Essays in Journal Therapy. Denver: Center for Journal Therapy.

Alexander, Bruce K. 2008. The Globalisation of Addiction: A Study in Poverty of the Spirit. Oxford: OUP.

Allen, Pat B. 1995. Art is a Way of Knowing. Boston: Shambala.

Andermahr, Sonya, and Silvia Pellicer-Ortín. 2013. Trauma Narratives and Herstory. Basingstoke: Palgrave Macmillan. [CrossRef]

Apostolos-Cappadona, Diane. 2020. A Guide to Christian Art. London: T\&T Clark Bloomsbury.

Barr, Beth Allison. 2021. The Making of Biblical Womanhood: How the Subjugation of Women Became Gospel Truth. Ada: Baker Publishing. Beal, Timothy. 2012. The Rise and Fall of the Bible: The Unexpected History of an Accidental Book. New York: Houghton Mifflin Harcourt.

Bedi, Ashok, and Joseph H. Pereira. 2020. The Spiritual Paradox of Addiction, The Call for the Transcendent. Lake Worth: Nicholas Hays, Inc.

Budd, Luann. 2002. Journal Keeping, Writing for Spiritual Growth. Downers Grove: IVP.

Burrus, Virgina. 1999. An Immoderate Feast: Augustine Reads John's Apocalypse. In History, Apocalypse, and the Secular Imagination: New Essay's on Augustine's City of God. Edited by Mark Vessey, Karla Pollmann and Allan D. Fitzgerald. Bowling Green: Philosophy Documentation Centre, pp. 183-94.

Byrd, Aimee. 2020. Recovering from Biblical Manhood and Womanhood: How the Church Needs to Rediscover Her Purpose. Grand Rapids: Zondervan.

Cepero, Helen. 2008. Journaling as a Spiritual Practice: Encountering God Through Attentive Writing. Downers Grove: IVP.

Claassens, L. Juliana M. 2020. Writing and Reading to Survive: Biblical and Contemporary Trauma Narratives in Conversation. Sheffield: Sheffield Phoenix Press.

DeWeerdt, Sarah. 2019. Tracing the US opioid crisis to its roots. Nature 573: S10-S12. [CrossRef] 
Dillon, Amanda. 2020. Be Your Own Scribe: Bible Journaling and the New Illuminators of the Densely Printed Page. In From Scrolls to Scrolling: Sacred Texts, Materiality, and Dynamic Media Cultures. Edited by Bradford A. Anderson. Berlin and Boston: De Gruyter, pp. 157-78. [CrossRef]

Etherington, Kim. 2008. Trauma, Drug Misuse and Transforming Identities. A Life Story Approach. London: Jessica Kingsley Publishers.

Fischer, Melissa, and Kate Peiffer. 2019. Bible Journaling for the Fine Artist. Mission Viejo: Quatro.

Gibney, Alex. 2021. The Crime of the Century. HBO Documentary. Available online: https://www.hbo.com/documentaries/thecrime-of-the-century (accessed on 27 July 2021).

Grisel, Judith. 2019. Never Enough: The Neuroscience and Experience of Addiction. London: Scribe.

Hall, James. 1994. Illustrated Dictionary of Symbols in Eastern and Western Art. London: John Murray.

Hassan, Sumayah. 2016. What is Quran Journaling? How do you set up your Quran Journal? November 27. Available online: https: / / www.recitereflect.com/what-is-quran-journaling/ (accessed on 27 July 2021).

Hieb, Marianne. 2005. Inner Journeying Through Art-Journaling: Learning to See and Record your Life as a Work of Art. London: Jessica Kingsley Publishers.

Jewitt, Carey. 2014. An Introduction to Multimodality. In The Routledge Handbook of Multimodal Analysis, 2nd ed. Edited by Carey Jewitt. London: Routledge, pp. 14-27.

Jones, Brian C. 2009. Wilderness. In NIDB. Nashville: Abingdon, vol. 5, pp. 848-52.

Kobes Du Mez, Kristin. 2020. Jesus and John Wayne: How White Evangelicals Corrupted a Faith and Fractured a Nation. New York: Liveright.

Kress, Gunther, and Theo van Leeuwen. 2021. Reading Images, The Grammar of Visual Design, 3rd ed. London: Routledge.

Leonard, Alison. 1995. Telling Our Stories: Wrestling with a Fresh Language for the Spiritual Journey. London: Darton, Longman and Todd.

Lukinsky, Joseph. 1990. Reflective Withdrawal Through Journal Writing. In Fostering Critical Reflection in Adulthood: A Guide to Transformative and Emancipatory Learning. Edited by Jack Mezirow and Assoc. San Francisco: Jossey-Bass.

Maisel, Eric, and Susan Raeburn. 2008. Creative Recovery, A Complete Addiction Treatment Program That Uses Your Natural Creativity. Boulder: Trumpeter.

Massyngberde Ford, J. 1975. Revelation. AYB. New Haven: Yale University Press.

Maté, Gabor. 2018. In the Realm of Hungry Ghosts: Close Encounters with Addiction. London: Vermillion.

Milner, Marion. 1986. A Life of One's Own. London: Virago.

Moon, Jennifer A. 2004. A Handbook of Reflective and Experiential Learning: Theory and Practice. London: RoutledgeFalmer.

Nichols Hickman, Lisa. 2013. Writing in the Margins: Connecting with God on the Pages of Your Bible. Nashville: Abingdon Press.

Ó Tuama, Pádraig. 2015. In the Shelter: Finding a Home in the World. London: Hodder and Stoughton.

Peace, Richard. 1995. Spiritual Journaling: Recording Your Journey Toward God. Colorado Springs: NavPress.

Pennebaker, James W. 2004. Writing to Heal: A Guided Journal for Recovering from Trauma E Emotional Upheaval. Denver: Center for Journal Therapy.

Plante, Thomas G. 2018. Healing with Spiritual Practices: Proven Techniques for Disorders from Addictions and Anxiety to Cancer and Chronic Pain. Santa Barbara: Praeger.

Progoff, Ira. 1975. At a Journal Workshop: Writing to Access the Power of the Unconscious and Evoke Creative Ability. New York: Penguin.

Progoff, Ira. 1983. Life-Study, Experiencing Creative Lives by the Intensive Journal Method. New York: Dialogue House.

Ringwald, Christopher D. 2002. The Soul of Recovery: Uncovering the Spiritual Dimension in the Treatment of Addictions. Oxford: OUP.

Rohr, Richard. 2011. Breathing Under Water: Spirituality and the Twelve Steps. Cincinnati: St Anthony Messenger Press.

Schüssler Fiorenza, Elizabeth. 1991. Revelation: Vision of a Just World. Edinburgh: T\&T Clark.

Stoicea, Nicoleta, Andrew Costa, Luis Periel, Alberto Uribe, Tristan Weaver, and Sergio D. Bergese. 2019. Current perspectives on the opioid crisis in the US healthcare system. A comprehensive literature review. Medicine 98: 20. [CrossRef] [PubMed]

Stulman, Louis. 2014. Reading the Bible through the Lens of Trauma and Art. In Trauma and Traumatisation in Individual and Collective Dimensions: Insights from Biblical Studies and Beyond. Edited by Eve-Marie Becker, Jan Dochhorn and Else K. Holt. Göttingen: Vandenhoeck and Ruprecht, pp. 177-92.

Szalavitz, Maia. 2019. Unbroken Brain: A Revolutionary New Way of Understanding Addiction. New York: Picador.

Theroux, Louis. 2017. Dark States—Heroin Town. BBC Documentary. Available online: https://www.bbcstudios.com/case-studies/ louis-theroux-dark-states-heroin-town/ (accessed on 27 July 2021).

Thompson, Leonard L. 1997. The Book of Revelation: Apocalypse and Empire. Oxford: OUP.

Unsworth, Len. 2008. Multimodal Semiotics: Functional Analysis in Contexts of Education. London: Routledge.

Van Leeuwen, Theo. 2005. Introducing Social Semiotics. London: Routledge.

Yarbro Collins, Adele. 1979. The Apocalypse. Dublin: Veritas. 